\title{
IMPLEMENTASI METODE LEARNING START WITH A QUESTION PADA PEMBELAJARAN AKIDAH AKHLAK
}

\author{
Latifatul Fauziah \\ Institut Agama Islam Negeri Kudus
}

\begin{abstract}
This research study aims to determine the implementation of the learning start with a question method in learning akidah morals at MA Mazro'atul Huda Wonorenggo Karanganyar Demak, as well as the supporting and inhibiting factors in this implementation. Qualitative method is a method used in this research, namely an approach that aims to understand a phenomenon in depth. The subjects of this research were the head of Madrasah, a teacher of akidah akhlak at MA Mazro'atul HudaWonorenggo Karanganyar Demak and one female student of class X IPA 1. Data about the implementation of the learning method start with a question on learning akidah akhlak at MA Mazro'atul. Huda Wonorenggo Karanganyar Demak was collected by interviewing, observing, and using documentation study. After the researcher went directly to the field and collected data accurately and analyzed it, the results showed that: First, the learning method start with a question is an innovative method in learning that can create situations and conditions for students to be much more active in learning and can develop the ability to ask questions about the material akidah morals given. The implementation of the learning method start with a question in learning akidah akhlak at MA Mazro'atul Huda Wonorenggo Karanganyar Demak has been implemented properly. Second, the supporting factors of the method, namely: from the mediator or educators, the factors of the education participants, the advantages of the learning start with a question method itself and the infrastructure such as the learning media used. The third, the inhibiting factors, namely: very limited time and factors from students.
\end{abstract}

Keywords: Methods, learning start with a question, learning akidah akhlak

Abstrak: Kajian penelitian ini bertujuan untuk mengetahui implementasi metode learning start with a question pada pembelajaran akidah akhlak di MA Mazro'atul Huda Wonorenggo Karanganyar Demak, serta faktor-faktor pendukung dan penghambat dalam pelaksanaan tersebut. Metode kualitatif merupakan metode yang digunakan pada penelitian ini, yaitu pendekatan yang bertujuan untuk memahami suatu fenomena secara mendalam. Subjek penelitian ini adalah Kepala Madrasah, guru mata pelajaran akidah akhlak di MA Mazro'atul HudaWonorenggo Karanganyar Demak serta satu peserta didik perempuan kelas $X$ IPA 1. Data-data tentang implementasi metode learning start with a question pada pembelajaran akidah akhlak di MA Mazro'atul Huda Wonorenggo Karanganyar Demak dikumpulkan dengan teknik wawancara atau interview, observasi, dan menggunakan studi dokumentasi. Setelah peneliti terjun langsung ke lapangan dan mengumpulkan datadata secara akurat serta menganalisisnya, maka hasil penelitian menunjukan bahwa: Pertama, metode learning start with a question merupakan sebuah metode inovasi dalam pembelajaran yang dapat menciptakan situasi dan kondisi peserta didik jauh lebih aktif dalam belajar serta dapat mengembangkan kemampuan bertanya 
tentang materi akidah akhlak yang diberikan. Implementasi metode learning start with a question pada pembelajaran akidah akhlak di MA Mazro'atul Huda Wonorenggo Karanganyar Demak sudah diimplementasikan dengan baik. Kedua, Faktor-faktor pendukung metode tersebut yaitu: dari mediator atau pendidik, faktor peserta ddik, kelebihan dari metode learning start with a question itu sendiri dan sarana prasarana misalnya media pembelajaran yang digunakan. Adapun ketiga, faktor-faktor penghambatnya yaitu: waktu yang sangat terbatas dan faktor dari peserta didik.

Kata Kunci: Metode, learning start with a question, pembelajaran akidah akhlak

\section{A. PENDAhuluan}

Dalam berbagai lini kehidupan, pendidikan memainkan peran yang sangat strategis karena memberi banyak peluang untuk meningkatkan mutu kehidupan. Pendidikan yang pada hakikatnya merupakan pengalaman-pengalaman belajar terprogram dalam bentuk pendidikan formal, non formal dan informal yang berlangsung seumur hidup bertujuan untuk mengoptimalkan kemampuan-kemampuan individu melalui kegiatan pengajaran, bimbingan atau latihan (Abdul Kadir 2014:60). Menurut Baharuddin berpendapat: pendidikan merupakan suatu kegiatan yang produktif dimana kegiatan yang mengandung banyak atau beberapa aktivitas antara mediator (pendidik) dengan anak didik yag didalamnya terdapat hubungan timbal balik dalam hal edukatif (Badruddin 2006:197). Dengan terciptanya pendidikan yang ideal, kemampuan yang ada pada diri manusia akan terus dapat memperlihatkan sisi perkembangan yang baik.

Salah satu konflik yang memang sedang gencar dalam dunia edukatif atau pendidikan saat-saat ini adalaah konflik mengenai lemahnya proses belajar mengajar atau pembelajaran. Dalam proses belajar mengajar tersebut, memang terlihat kurangnya dorongan untuk peserta didik dalam memeberikan partisipasi aktif baik secara tatap muka sehingga belajar peserta didik belum dapat dikatakan optimal dimana melihat peserta didik yang seharusnya berperan sebagai subjeknya.

Kegiatan atau proses belajar mengajar menjadi hal penting yang menjadi satu kesatuan dalam berlangsungnya proses atau sistem pendidikan dengan menempatkan mediator sebagai pemegang peran utama. Proses yang tercipta dalam belajar mengajar dapat dikatakan sebagai kumpulan interaksi antara mediator atau pendidik dengan anak didik dalam dunia edukatif guna tercapainya educational goals (Moh Uzer Usman 2006:4). Maka dari itu, dalam menyelenggarakan proses mengajar pendidik atau mediator lebih dituntut untuk memahami proses belajar peserta didik. 
Penggunaan metode pembelajaran menjadi salah satu alternatif yang dapat diwujudkan dalam membangkitkan gairah semangat peserta didik karena metode pembelajaran yang sesuai dapat memudahkan peserta didik mencerna bahan ajar atau materi yang diajarkan oleh gurunya dan tidak adanya kesulitan pesera didik dalam proses pembelajaran. Pemanfaatan metode pembelajaran yang tidak selaras akan menjadi problem untuk mencapai educational goals yang direncanakan. Ketidaksesuaian pemanfaatan metode dalam pembelajaran mengakibatkan terbuangnya bahan pelajaran dengan percuma (Satrio Wicaksono 2016:276). Oleh sebab itu, keefektifan penggunaan atau pemanfaatan pembelajaran bisa dikatakan sangat berpengaruh terhadap pencapaian tujuan pembelajaran. Akibat bagi anak didik yang mengalami kesukaran atau kesilatan dalam belajar ditandai dengan kepasifan dari peserta didik serta prestasi belajar yang rendah. Hal tersebut berdasarkan contoh kasus pada jurnal dari penelitian yang dilakukan oleh Iin Nurbudiyani dan Nopi mengatakan bahwa dalam berlangsungnya pembelajaran, mayoritas perhatian beberapa anak didik tidak terpusat pada bahan ajar yang sedang diberikan, berbicara sendiri, mengganggu temannya, bahkan seringnya tidak ada yang mengajukan pertanyaan meskipun guru telah memberikan kesempatan untuk menanyakan materi yang belum dipahaminya (Iin Nurbudiyani 2017:22).

Kesulitan lain yang juga dialami oleh peserta didik berdasarkan hasil yang diutarakan dalam jurnal oleh Lingga Nico Pradana yang berjudul "Keefektivan Metode Learning Starts with a Question Pada Pembelajaran Geometri”. Ia menjelaskan dalam jurnalnya bahwa tidak banyak sumbersumber bahan ajar yang dapat dengan mudah memberikan pemahaman peserta didik. Dimana problem atau kendala yang dialami peserta didik secara tidak langsung dapat berpengaruh terhadap pembelajaran yang menjadikannya tidak maksimal (Lingga Nici Pradana 2016:12). Dari kasus-kasus tersebut diatas membuktikan bahwa effective learning process sangat diperlukan guna mendukung tercapainya tujuan pembelajaran.

Salah satu bagian dalam pelajaran PAI (pendidikan agama Islam) yaitu pelajaran akidah ahlak. Pelajaran ini tidak hanya terfokus dengan norma aturan yang mengatur hubungan antar sesama manusia dan juga tidak hanya menyinggung mengenai persoalan teoritis yang bersifat kognitif semata, akan tetapi pengetahuan akidah ahlak yang bersifat kognitif dapat diubah menjadi bermakna dan dapat diimplementasikan terhadap perilakuperilaku keseharian dan juga memuat norma aturan yang mengatur hubungan manusia 


\section{Latifatul Fauziah}

dengan Tuhan nya bahkan hubungan dengan alam semesta (Dewi Prasari Suryawati 2016:313). Kenyataannya, pembelajaran akidah akhlak menghadapi beberapa kendala. Adapun kendala tersebut diantaranya: waktu yang disedikan terbatas sedang materi begitu padat dan luas, minimnya pengaplikasian dalam pembentukan sikap dikarenakan bahan ajar hanya terfokus pada pengayaan pengetahuan yang ada, masih banyaknya pengembangan pendekatan dan metode yang kurang bervariatif karena lemahnya dalam sumber dayapendidik. Maka dengan mewujudkan pembelajaran yang menarik dan bermakna, guru membutuhkan inovasi dalam pembelajaran agar menjadikan anak didik lebih dapat berpartisipasi aktif sehingga mampu dalam mengembangkan kemampuan (potensi) berpikir peserta didik (Reisa Farida Amri 2016:54).

Guru yang mengajar akidah akhlak belum menerapkan dengan betul metode pembelajaran yang mampu mengubah iklim belajar mengajar dengan lebih kondusif. Kaitan dalam hal ini dilihat dari pemanfaatan atau penggunaan metode yang masih bernuansa monoton, yakni hanya mencatat, ceramah, dan sedikit sekali tanya jawab. Keunggulan ceramah sebagai metode yang murah dan mudah dilaksanakan ternyata tidak sebanding dengan akibat negatif yang ditimbulkannya. Secara tidak sadar guru telah mengambil alih segala aktivitas pembelajaran. Hal ini mengesankan bahwa dia sebagai subjek dari pembelajaran itu sendiri. Sementara kebutuhan siswa dalam pembelajaran itu, seakan diabaikan. Siswa tidak lebih sebagai objek penderita. Hal ini kemudian mengakibatkan siswa menjadi pasif, bahkan materi pelajarannya pun yang selalu didengar dari penjelasan guru menjadi sangat mudah terlupakan. Menurut Said Alwi dalam jurnalnya dijelaskan bahwa "jika dalam pembelajaran di kelas guru mengajar hanya dalam bentuk ceramah yang berarti siswa menyaksikan dan mendengarkan penjelasan dari guru, maka siswa hanya dapat mengingat sedikit dari apa yang didengar"(Said Alwi 2017:147).

Di sisi lain kepasifan yang benar terjadi pada sebagian peserta didik dalam belajarnya yaitu dalam mengajukan pertanyaan dan rendahnya prestasi belajar mata pelajaran aqidah akhlak. Hal tersebut dipicu oleh sarana prasarana yang memang belum memadai. Hal tersebut dibuktikan dari keberadaan perpustakaan madrasah tidak representatif, baik lokasi maupun koleksi bukunya, serta media pembelajaran yang sangat terbatas.

Permasalahan yang diutarakan di atas juga terjadi di MA Mazro“atul Huda Wonorenggo Karanganyar Demak. Berdasarkan observasi pendahuluan yang dilakukan oleh 
peneliti, berangkat dari MA Mazroatul Huda Wonorenggo Demak yang merupakan tempat pelaksanaan KKN IK yang telah dilakanakan, diperoleh informasi bahwa proses pembelajaran belum berjalan optimal. Peneliti mendapatkan gambaran terlihat siswa kurang antusias dalam belajar. Hal tersebut juga terjadi atau ditemukan beberapa permasalahan dikelas yaitu kurang adanya kesiapan (preparation) dalam mencerna materi pembelajaran, dapat dibuktikan ketika pembelajaran peserta didik lebih memilih bermain, bersendau gurau dengan kawan-kawannya, bahkan terlihat beberapa anak didik yang tidur selama proses pembelajaran. Pesertadidik cenderung tidak ada yang bertanya tentang materi pelajaran padahal pendidik atau mediator mencoba memberikan pancingan kesempatan anak didik untuk bertanya. Pendidikpun juga memberikan keleluasaan mencari dan mengelola materi ajar yang diajarkan.

Permasalahan-permasalahn tersebut memang perlu untuk segera ditindak lanjuti. Salah satu penindak lanjtan tersebut dapat diatasi dengan pengapilkasian metode agar pembelajaran menyenangkan. Metode learning start with a question menjadi salah satu jawaban alternatif yang merupakan cooperative learnign (Agus Suprijono 2016:130).Salah satu tujuan pembelajaran kooperatif adalah untuk membangkitkan gairah partisipasi anak didik dalam kegiatan pembelajaran untuk mencapai learning goals (Dr Arifin 2017:83). Pemilihan metode ini dapat dikatakan sesuai karena dianggap mampu membangkitkan kemampuan aktif pesera didik dan terciptanya material discussion dengan semestinya.

Berdasarkan hasil wawancara telahdilakukan oleh peneliti kepada pendidik pengampu pelajaran akidah ahlak di MA Mazroatul Huda Wonorenggo Karanganyar Demak yakni Bapak Akhmad Mukhammad, S.Pd. I yang menyatakan bahwa sudah mengembangkan inovasi dalam pembelajaran dengan menggunakan metode learning start with a question di MA Mazro"eatul Huda Wonorenggo Karanganyar Demak. Hal tersebut dilakukan oleh Akhmad Mukhammad, S.Pd. I karena dengan menggunakan learning start with a question tersebut diharapkan anak didik dapat berpartisipasi untuk lebih aktif lagi dan kemampuan bertanyanya meningkat sehingga tidak lagi adanya istilah pembelajaran monoton. Meski demikian implementasi metode tersebut terhadap pelajaran akidah akhlak tetap harus memerhatikan bahan ajar yang sedang di ajarkan.

Dengan penerapan learning start with a question diharapkan siswa dapat meningkatkan kemampuan partisipasi aktifnya pembelajaran, khususnya kemampuan 


\section{Latifatul Fauziah}

bertanya. Proses mempelajari sesuatu yang baru adalah lebih efektif jika siswa aktif mencari dari pada sekedar menerima. Salah satu cara menciptakan pola belajar aktif ini adalah merangsang siswa untuk bertanya tentang materi pelajaran mereka, tanpa penjelasan dari guru terlebih dahulu.

Berdasarkan keseluruhan paparan permasalahan di atas, maka membangkitkan penulis untuk mendapatkan gambaran konkrit, mengulas, dan membahas dalam sebuah penelitian lebih lanjut dalam bentuk skripsi yang berjudul "Implementasi Metode Learning Start wiht a Question pada Pembelajaran Akidah Akhlak di MA Mazroatul Huda Wonorenggo Karanganyar Demak”.

\section{B. Metode}

Penelitian ini menggunakan jenis penelitian yang tergolong dalam penelitian lapangan (field research) yakni penelitian yang dilakukan dalam situasi alamiah dengan mengamati fenomena di lapangan oleh peneliti yang menggunakan informan atau responden melalui instrumen pengumpulan data, wawancara, observasi, dan sebagainya. Penelitian ini juga bisa disebut sebagai penelitian kasus atau studi kasus (case study) (Suharsimi Arikunto 2006:120-123).

Sedangkan pada penelitian ini menggunakan pendekatan kualitatif, yakni suatu penelitian yang ditujukan untuk mendeskripsikan dan menganalisa fenomena, peristiwa, aktivitas sosial, persepsi, pemikiran orang baik secara individual maupun kelompok secara mendalam dalam konteks situasi dan watu yang bersangkutan sesuai dengan kondisi objektif di lapangan. Pemilihan penggunaan pendekatan kualitatif sebagai pendekatan penelitian ini adalah karena peneliti ingin melihat, meneliti dengan lebih dekat tentang implementasi metode learning start with a question pada pembelajaran akidah akhlak di MA Mazro'atul Huda Wonorenggo Karanganyar Demak.

\section{HASIL DAN PEMBAHASAN}

\section{Pengertian Implementasi}

Secara istilah, implementasi merupakan proses pelaksanaan ide, gagasan, atau kegiatan-kegiatan baru dengan harapan seseorang dapat menyesuaikan dan melaksanakan demi terciptanya tujuan yang mampu untuk dicapai dengan jaringanjaringan pelaksana yang dapat dipercaya (Indra Kurniawan 2018:4). 
Fullan memberikan definisi mengenai implementasi bahwa implementasi merupakan proses suatu peletakan dalam praktik tentang suatu program, ide, atau seperangkat aktivitas dengan harapan terjadinya sebuah perubahan (change). Senada dengan hal tersebut implementasi juga dikemukakan oleh Diding Rahmat bahwa implementasi merupakan proses untuk menilai, mengevaluasi dan mengukur peraturan dan kebijakan daat berjalan dengan baik atau tidak. Selanjtnya akan dinilai apakah harus ada evaluasi atau tidak terhadap program tersebut (Didin Rahmad 2017:37)

Berdasarkan pendapat-pendapat di atas, maka dapat disimpulkan implementasi adalah suatu kegiatan yang terancang yang harus dilaksanakan dengan kesungguhan berdasarkan norma atau aturan tertentu untuk mencapai tujuan kegiatan yang diinginkan. Oleh sebab itu, implementasi dipengaruhi oleh objek selanjutnya yaitu kurikulum, tidak dapat berdiri sendiri. Implementasi kurikulum itu sendiri yang nanti menjadi proses pelaksanaan dari program, ide, atau aktivitas baru dengan harapan terjadinya perubahan terhadap suatu proses pembelajaran bagi orang lain untuk menerima dan melakukannya guna memperoleh hasil yang diinginkan.

\section{Pembelajaran}

\section{a. Pengertian Pembelajaran}

Pembelajaran merupakan elemen atau bagian yang memiliki peran dominan yang berorientasi pada suatu tujuan yang ingin dicapai dengan mewujudkan kualitas pendidikan, baik kualitas pada proses maupun hasil (output). Pembelajaran yang dilaksanakan dengan cara yang kurang bahkan tidak tepat dapat mengakibatkan potensi peserta didik sulit diberdayakan atau dikembangkan, sebaliknya pembelajaran yang dilaksanakan secara baik dan tepat dapat memberikan kontribusi sangat dominan bagi peserta didik. Karena pembelajaran memilik dampak atau pengaruh yang dapat menyebabkan kualitas pendidikan menjadi rendah, artinya pelaksanaan pembelajaran atau pengemasan proses pembelajaran disini sangat tergantung pada kemampuan seorang pendidik ( $\mathrm{M}$ Saekhan Muchit 2008:1). Rangkaian kegiatan pembelajaran itu nantinya yang akan memberikan pengalaman belajar melalui interaksi antara peserta didik dan 
guru, sumber belajar dan lingkungan dengan melibatkan proses mental dan fisik dalam rangka mencapai tujuan pembelajaran (Putri Widyanto 2019:83).

Sebelumnya kata pembalajaran dikenal dengan istilah pengajaran. Istilah "proses belajar mengajar" atau "kegiatan mengajar" yang tidak asing lagi. Dari kedua istilah tersebut, ada dua istilah yaitu "belajar" dan "mengajar". Keduanya seolah tidak dapat dipisahkan satu sama lain. Tetapi perlu diketahu bahwa istilah pembelajaran itu mengandung makna yang lebih luas dari mengajar, yang artinya pembelajaran merupakan usaha yang dilaksanakan secara sengaja, terencana, dan terarah dengan tujuan yang telah diprogramkan sebelumnya, serta pelaksanaannya sangat terkendali, dengam maksud agar terjadi belajar pada diri seseorang. Sedangkan proses belajar dapat terjadi kapan saja terlepas dari ada atau tidak adanya yang mengajar. Adanya interaksi antar satu individu dengan lingkungannya itulah bisa dikatakan telah terjadinya proses belajar (Eveline Siregar 2014:4-5).

Dari uraian di atas, dapat disimpulkan bahwa pembelajaran adalah proses dimana terjadinya interaksi antara seorang pendidik dengan peserta didik, dan sumber belajar. Interaksi terjadi dalam suatu lingkungan belajar yang melibatkan guru dan peserta didik saling memberikan dan menerima atau saling bertukar informasi untuk mecapai tujuan yang diharapkan.

\section{b. Prinsip-Prinsip Belajar dan Pembelajaran}

Sebelum memulai proses pembelajaran, ada beberapa hal yang harus diperhatikan dan dipahami, yakni mengenai prinsip-prinsip belajar dan pembelajaran. Proses belajar akan bermakna apabila dapat memperhatikan prinsip-prinsip belajar, dan akan menemukan kegagalan apabila prinsip-prinsip belajar tidak diperhatikan dengan baik. Hal ini dilakukan semata untuk memilih dan menetukan metode pembelajaran yang akan diterapkan dalam proses belajar mengajar. Adapun prinsip-prinsip tersebut antara lain, sebagai berikut:

1) Prinsip Motivasi

Peran yang sangat penting dalam belajar salah satunya adalah motivasi (motivation). Rasa ingin tahu yang kuat untuk ikut serta dalam kegiatan belajar, menunjukkan minat dan perhatiannya terhadap kegiatan belajar, serta mencurahkan segala kemampuannya untuk mempelajari hal-hal tertentu, 
hingga kesungguhan dalam ia mendapatkan apa yang diharapkan merupakan beberapa ciri-ciri adanya motivasi yang tinggi dari peserta didik untuk belajar. Tidak dapat dipungkiri, setiap tindakan yang dilakukan oleh manusia selalu dimulai dengan motivasi (niat).

Pada proses pembelajaran khususnya pembelajaran pada pendidikan agama Islam, peserta didik sangat diupayakan untuk dapat menimbulkan adanya motivasi dengan kolaborasi penerapan metode pembelajaran. Karena hal ini dapat memberikan stimulus motivasi belajar pada peserta didik. Dan dengan motivasi juga dapat diupayakan dengan menciptakan suasana lingkungan yang baik yang akan memotivasinya untuk belajar dan mencapai tujuan yang diharapkan.

2) Prinsip partisipasi aktif peserta didik

Salah satu prinsip yang sangat penting dalam pembelajaran yaitu prinsip partisipasi aktif ini. Minat belajar peserta didik yang tinggi dengan tercurahnya perhatian pada kegiatan belajar mengajar akan memacu peserta didik ke suasana dimana ia dapat aktif dalam mengikuti perjalanan kegiatan pembelajaran dengan baik. Partisipasi aktif ini tidak dapat dilihat hanya dari badaniyahnya saja, tetapi juga aqliyah dan batiniyahnya, seperti hal nya perhatiannya yang terfokus pada isi ceramah yang disampaikan, berdiskusi, mengerjakan tugas, dan lain sebagainya. Sehingga pikiran dan perasaan peserta didik tidak berpindah pada obyek lain. Dalam merancang rencana pembelajaran yang akan diterapkan hendaknya guru menyiapkan cara yang sesuai agar peserta didik dapat berpartisipasi aktif dalam proses belajar mengajar, tidak menjadi peserta didik yang pasif.

3) Prinsip Retensi

Prinsip retensi ini merupakan prinsip yang dilakukan dengan mengingat kembali materi ajar yang sudah diberikan dan diajarkan oleh pendidik atau guru kepada peserta didik. Dengan adanya pengulangan maka akan jauh lebih mudah peserta didik dalam menanamkan konsep, informasi, realita, pemahaman, dan pemikiran ke dalam memori otak mereka. Berkaca dari hal itu, guru hendaknya dapat membiasakan dalam melakukan pengulangan tersebut. Karena dengan hal ini akan sangat lebih efektif dalam memahamkan peserta didik tentang apa yang disampaikannya. Pengulangan 
yang baik dan menarik juga akan memiliki dampak positif dalam membangkitkan motivasi belajar mereka dan pastinya pembelajaran akan jauh lebih bermakna.

4) Prinsip Kesiapan ( Readines)

Salah satu faktor yang dapat mempengaruhi proses belajar mengajar adalah prinsip kesiapan ini. Prinsip yang dimaksud adalah siapnya peserta didik terhadap kondisi psikis dan fisiknya. Peserta didik yang belum siap dalam menerima pembelajaran akan berakibat peserta didik mengalami kesulitan dalam belajar bhakan putus asa dalam belajar. Kesiapan ini meliputi kematangan dan petumbuhan fisik dan psikis, tingkat kepandaian, pengalam belajar sebelumnya, motivasi, dan lain-lain.

Sehingga untuk mempersiapkan rancangan pembelajaran perlu diperhatikan beberapa hal berikut ini:

a) Kemampuan peserta didik, latar belakang pengalaman, dan tingkat usia harus diperhatikan untuk menyesuaikan materi atau tugas yang akan diberikan.

b) Sebelum memulai pembelajaran perlu dilakukan tes untuk mencari tahu tingkat kesiapan dan kemampuan peserta didik.

c) Bahan-bahan dan tugas-tugas belajar dipersiapkan dengan banyak variasi yang sesuai dengan kesiapan kognitif, afektif, dan psikomotor peserta didik.

5) Prinsip Persepsi

Proses yang bersifat kompleks yang dapat menyebabkan seseorang mampu menerima dan menyerap pengetahuan atau informasi dari lingkungannya, merupakan pemaknaan dari persepsi. Persepsi ini juga termasuk permulaan dari proses belajar mengajar karena biasanya dianggap sebagai tahap awal pemahaman peserta didik pada kognitifnya. Oleh sebab itu, penanaman persepsi yang baik dan akurat mengenai apa yang telah dipelajari sangat penting untuk ditanamkan sejak dini. Apabila memiliki persepi yang salah, akan mengakibatkan kesulitan pada peserta didik dalam merubah persepsi yang sudah melekat pada dirinya (Heri Gunawan 2014:147-150)).

\section{c. Faktor-Faktor yang Mempengaruhi Belajar}


Menurut Ngalim Purwanto dalam bukunya yang berjudul "Psikologi Pendidikan" mengatakan bahwa faktor-faktor yang mempengaruhi belajar, dibagi menjadi dua bagian:

1) Faktor pada diri organisme itu sendiri atau yang biasanya disebut dengan faktor individual. Adapun yang termasuk faktor individual yaitu faktor kematangan/ pertumbuhan, motivasi, latihan, kecerdasan, dan faktor pribadi.

2) Faktor yang berada diluar individu atau yang biasa disebut faktor sosial Contoh dari faktor sosial sendiri adalah faktor keluarga (ruman tangga), alatalat yang digunakan dalam belajar mengajar, guru dan cara mengajarnya, lingkungan, dan kesempatan yang tersedia serta motivasi sosial (Ngalim Purwanto 2004:102).

Berdasarkan beberapa faktor di atas, dapat ditarik benang merah bahwa faktor yang mempengaruhi belajar dapat dibagi ke dalam 2 faktor, yakni:

1) Faktor Internal

Faktor internal merupakan hal-hal atau suatu keadaan yang muncul dari dalam diri peserta didik sendiri. Seperti halnya, kondisi jasmani dan rohani peserta didik, kematangan/pertumbuhan, kecerdasan, minat, latihan dan kebiasaan belajar, motivasi pribadi dan konsep diri. Faktor ini merupakan faktor penting dalam menunjang keberhasilan proses belajar peserta didik (Vella Anggresta 2016:98).

2) Faktor Eksternal

Sedangkan Faktor Eksternal merupakan kebalikan dari faktor internal yaitu hal-hal atau keadaan-keadaan yang muncul dari luar peserta didik. Faktor eksternal tersebut meliputi faktor keluarga, faktor sekolah, dan faktor masyarakat. Faktor ini juga penting dalam menunjang keberhasilan proses belajar peserta didik (Nevy Farista Aristin 2015:31).

\section{d. Pembelajaran Akidah Akhlak}

1) Pengertian Pembelajaran Akidah Akhlak

Dalam bahasa Indonesia, akhlak secara umum memiliki makna "tingkah laku" atau "budi pekerti". Asal muasal kata "akhlak" berasal dari bahasa Arab, yang bermakna bentuk kejadian; artinya tentu bentuk batin (psikis) seseorang. Salah satu ulama memberikan definisi mengenai akhlak 
yaitu Imam Ghazali bahwa akhlak merupakan suatu istilah tentang bentuk batin yang ada dalam jiwa seseorang, bukan suatu pemikiran dan bukan pula suatu pertimbangan, tetapi dorongan seseorang untuk berbuat atau bertingkah laku (Zakiyah Drajad 2001:62-70). Sedangkan pembelajaran rangkaian proses penyampaian materi pelajaran dari seorang pendidik kepada pesera didik (Hamdani 2011:23).

Pembelajaran akidah akhlak memiliki peranan penting dalam membentuk tingkah laku siswa. Sebab dengan adanya pembelajaran akidah akhlak, peserta didik diarahkan kepada pencapaian kebahagiaan hidup di akhirat, tidak hanya untuk pencapaian kebahagiaan hidup di dunia saja. Peserta didik akan diarahkan untuk mencapai keseimbangan antara hubungan antar manusia dengan lingkungannya dalam kehidupan sosial, keseimbangan antara kemajuan lahiriah dan batiniah, juga hubungan antara manusia dengan Tuhan (hablum min Allah wa hablum min an-nas). Selain itu, diharapkan dengan pembelajaran Akidah Akhlak, peserta didik akan memiliki derajat yang tinggi melebihi makhluk lainnya (Muamar 2018:177).

2) Tujuan Pendidikan Akhlak

Tujuan utama dalam pendidikan akhlak adalah mempertinggi nilainilai akhlak hingga mencapai tingkat akhlak al-karimah. Tujuan ini sama atau sebangun dengan tujuan dalam misi kerasulan yang ingin dicapai, yaitu membimbing manusia agar berakhlak mulia. Kemudian akhlak mulia tersebut dapar tercermin dalam sifat, sikap atau tingkah laku individu pada hubungannya dengan Allah SWT, diri sendiri, antar manusia, dan sesama makhluk Allah SWT serta lingkungannya (Yoke Suryadarma 2015:367).

\section{e. Faktor Pendukung dan Penghambat Pembelajaran}

Riya Riyani mengungkapkan dalam jurnalnya bahwa faktor yang dapat menjadi pendukung maupun penghambat dalam pembelajaran yaitu faktor guru, faktor peserta didik, sarana prasarana serta faktor lingkungan sekolah.

1) Faktor Guru

Guru atau pendidik merupakan komponen yang amat penting dalam proses pembelajaran. Keberhasilan proses belajar mengajar tergantung pada 
kepiawaian guru dalam menggunakan metode, strategi maupun taktik pembelajaran. Selain sebagai model atau teladan bagi peserta didiknya, guru juga berperan sebagai pengelola pembelajaran.

2) Faktor peserta didik

Adapun faktor dari peserta didik meliputi aspek dari sifat peserta didik itu sendiri, yaitu kemampuan dasar, sikap dan penampilan, adakalanya siswa sangat aktif dan adakalanya juga peserta didik yang kita didik sangat pendiam dan malah yang sangat disayangkan peserta didik tersebut memiliki motivasi yang rendah dalam belajar.

3) Faktor sarana prasarana

Sarana merupakan faktor yang mempengaruhi dan sangat penting dalam kelancaran prses pembelajaran, misalnya media pembelaaran, alat pembelajaran, perlengkapan sekolah. Sedangkan prasarana merupakan segala sesuatu yang tidak langsung dapat mendukung keberhasilan proses belajar mengajar, misalnya penerangan sekolah dan sebagainya. Beberapa pengaruh tersebut dapat menumbuhkan gairah dan motivasi guru dalam mengajar serta dapat memberikan berbagai pilihan pada peserta didik untuk belajar.

4) Faktor Lingkungan

Faktor lingkungan terdiri dari faktor organisasi kelas dan faktor iklim sosial-psikologis. Faktor organisasi kelas meliputi jumlah peserta didik dalam satu kelas, organisasi kelas yang terlalu besar akan kurang efektif untuk mencapai tujuan pembelajaran.Sedangkan faktor sosial-psikologis menyangkut keharmonisan hubungan antar orang yang terlibat dalam proses belajar mengajar (Yani Riyani 2015:19-20).

Berdasarkan konsep keseluruhan mengenai pembelajaran tersebut, kegiatan pembelajaran bermuara pada dua kegiatan pokok, sebagai berikut:

a. Bagaimana seseorang itu melakukan sebuah tindakan perubahan tingkah laku melalui kegiatan belajar. 
b. Bagaimana seseorang melakukan sebuah tindakan (action) dalam penyampaian ilmu pengetahuan melalui kegiatan pembelajaran itu.

\section{f. Pembelajaran Kooperatif (Cooperative Learning)}

1) Pengertian Pembelajaran Kooperatif

Pembelajaran kooperatif atau yang sering disebut dengan cooperative learning merupakan serangkaian kegiatan belajar peserta didik yang mengacu pada pembelajaran, yang mana peserta didik bekerjasama dalam kelompok kecil saling membantu dalam belajar untuk mencapai tujuan belajar yang dirumuskan. Pertanggung jawaban atas ketuntasan tugas-tugas kelompok dan untuk mempelajari materi itu ditanggung oleh anggotaanggota kelompok masing-masing (Jamil Suprihatiningrum 2017:191).

Pembelajaran kooperatif atau cooperative learning memiliki empat unsur yang sangat penting dalam pembelajarannya, yaitu: peserta didik, aturan, upaya belajar setiap anggota kelompok, dan tujuan yang akan dicapai. Peserta didik adalah siswa-siswi yang terlibat dalam proses pembelajaran setiap kelompok belajar. Pengelompokan peserta didik bisa dilakukan dengan berbagai sudut pandang, diantaranya pengelompokan berdasarkan bakat dan minat peserta didik, berdasarkan latar belakang kemampuan peserta didik dan lain-lain. Sedangkan aturan kelompok merupakan segala sesuatu yang ditentukan berdasarkan kesepakatan bersama dengan semua pihak yang terlibat. Misalnya waktu dan tempat pelakasanaan, pembagian tugas anggota kelompok dan sebagainya. Kemudian upaya belajar yang termasuk adalah segala aktivitas peserta didik untuk meningkatkan kemampuan dalam dirinya baik kemampuan yang sudah dimilikimaupun kemampuan baru. Terakhir yaitu aspek tujuan, yang dimaksud aspek tujuan untuk memberikan arah perencanaan, pelaksanaan, dan evaluasi, Setiap anggota kelompok dapat memahami umpan atau sasaran sari setiap kegiatan belajar melalui tujuan yang jelas.

2) Tujuan Pembelajaran Kooperatif

Arent mengungkakan bahwa the cooperative learning model was developed to achieve at least three important instructional goals: academic achievement, acceptance of diversity, and social skill delopment. Maksudnya 
adalah model pembelajaran kooperatif dikembangkan guna mencapai sekurang-kurangnya ada tiga tujuan penting dalam pembelajaran, yaitu hasil belajar akademik, pemenerimaan perbedaan individu, dan pengembangan ketrampilan social peserta didik (Jamil Suprihantiningrum 2017:197).

3) Keunggulan dan Kelemahan Pembelajaran kooperatif

Adapun keunggulan atau kelebihan dari pembelajaran kooperatif (cooperative learning) ini adalah, sebgai berikut:

a) Menambah kepercayaan kemampuan berpikir sendiri bagi peserta didik, menemukan informasi dari berbagai sumber dan belajar dari peserta didik lain. Peserta didik diajarkan untuk tidak bergantung pada guru.

b) Menumbuh kembangkan kemampuan mengungkapkan gagasan, pendapat, atau ide dengan kata-kata yang baik dan membandingkannya dengan agasan-gagasan orang lain.

c) Menciptakan sikap respect pada orang lain, menyadari atas segala kekurangannya, dan bersedia menerima beberapa perbedaan.

d) Membantu dalam memberdayakan setiap peserta didik untuk lebih bertanggung jawab dalam belajar.

e) Meningkatkan motivasi dan memberikan rangsangan serta stimulus positif untuk berpikir dan hal ini berguna untuk proses pendidikan jangka panjang.

Adapun keterbatasan atau kekurangan dari pembelajaran kooperatif (cooperative learning) adalah, sebagai berikut:

a) Ciri utama dari pembelajaran kooperatif adalah peserta didik saling membelajarkan. Oleh sebab itu, tanpa adanya peer teaching yang tepat dan efektif, bisa jadi cara belajar yang demikian peseta didik tidak bisa memahami apa yang seharusnya dipahami.

b) Memahami dan mengerti filosofis pembelajaran kooperatif membutuhkan waktu yang tidak sebentar. Untuk peserta didik yang memiliki kelebihan, mereka akan merasa terhambat oleh peserta didik yang dianggap kurang memiliki kemampuan. Akibat dari itu dapat mengganggu iklim kerja sama kelompoknya. 
c) Penilaian dalam pembelajaran koopertaif dilihat berdasarkan hasil kerja kelompok. Namun perlu disadari bahwa sebenarnya prestasi atau hasil yang diharapka peserta didik adalah prestasi setiap individu peserta didik.

d) Walaupun kemampuan kerja sama merupakan kemampuan yang sangat penting, tetapi banyak aktifitas dala kehidupan yang hanya didasarkan kepada kemampuan secara individual (Hamruni 2009:170)

Maka dari itu dalam model pembelajaran kooperatif ini dibutuhkan metode pembelajaran yang sesuai agar pembelajaran menjadi lebih menarik dan menyenangkan. Penggunaan metode pembelajaran yang menarik dan menyenangkan dapat meningkatkan antusias dan gairah peserta didik untuk memperhatikan materi pembelajaran yang sedang diajarkan. Selain itu pembelajaran yang terencana semacam ini akan menciptakan pembelajaran yang aktif dan efektif.

\section{Metode Pembelajaran Learning Start With a Question}

\section{a. Pengertian Metode Pembelajaran}

Kata metode berasal atau diambil dari bahasa Yunani, yaitu meta dan hodos. Meta sendiri memiliki makna melalui, sedangkan hodos memiliki makna jalan. Menurut bahasa, biasanya istilah metode sering diartikan dengan "cara". Dengan demikian, metode dapat diartikan sebagai cara atau jalan yang harus dilalui untuk mencapai suatu tujuan. Langgulung memberikan definisinya mengenai metode bahwa sebenarnya metode memang jalan untuk menuju ke tujuan yang ingin diharapkan. Jalan yang dimaksud disini adalah posisi bagaimana cara menemukan, menguji, dan menyusun data bagi proses pengembangan ilmu (Heri Gunawan 2014, 255 ).

Sedangkan dalam bahasa Arab, metode dikenal dengan istilah thariqah. Thariqah sendiri memiliki makna langkah strategis dalam mempersiapkan suatu pekerjaan, atau dalam istilah pendidikan yaitu langkah-langkah yang diambil pendidik guna membantu dalam merealisasikan tujuan tertentu (Novan Ardy 2016:185).

Dalam pendidikan, istilah metode mengandung maksud atau makna yang berdekatan dengan beberapa istilah, diantaranya yaitu pendekatan dan strategi 
atau teknik. Lughawinya, pendekatan merupakan proses, cara, perbuatan mendekati. Secara istilahnya, sifat dari pendekatan itu aksiomatais yang menyatakan keyakinan, pendirian, paradigma terhadap subject matter yang harus ada dalam proses pendidikan yang kemudian melaporkan metode pendidikan. Sedangkan strategi atu teknik merupakan cara yang lebih spesifik untuk mengajar suatu kemahiran oleh pendidik dalam wujud activity, taktik, strategi dan alat yang terkait dengannya. Tetapi dari ketiganya, pada intinya adalah suatu cara yang tepat dan cepat untuk mencapai tujuan pendidikan yang ditetapkan yang sesuai dengan kebutuhan peserta didik (Novan Ardy 2016:186).

Menurut istilah (terminologis), terdapat beragam definisi yang dikemukakakn oleh para ahli, terlebih lagi jika metode itu sudah dikolaborasikan atau disandingkan dengan kata pembelajaran, diantaranya:

1) Menurut Al-Abrasyi mendefinisikan bahwa metode sebagai jalan yang kita ikuti untuk memberikan pemahaman kepada peserta didik dalam segala macam mata pelajaran.

2) Menurut Ramayulis, ia mengungkapkan bahwa metode adalah cara yang digunakan guru dalam menciptakan hubungan dengan pesera didik pada saat berlangsungnya proses pembelajaran dan yang merupakan alat untuk menciptakan proses pembelajaran (Heri Gunawan 2014, 256).

Berdasarkan definisi yang diutarakan para ahli di atas, dapat ditarik kesimpulan bahwa metode pembelajaran adalah cara-cara yang digunakan oleh pendidik dalam menyajikan materi atau bahan ajar kepada peserta didik supaya terjadinya proses pembelajaran pada peserta didik dalam upaya mencapai tujuan pembelajaran.

Dalam proses pembelajaran islam, metode pembelajaran merupakan faktor penting yang dominan dalam tercapainya tujuan pendidikan. Metode yang efektif dan tepat maka materi pembelajaran yang disampaikan itu akan berjalan dengan lancar (Dimas Ahmad Sabrani 2015:45). Sehingga bisa dikatakan bahwa metode pendidikan ini memiliki posisi yang sangat signifikan. Sebaik apapun tujuan pendidikan dibuat, apabila metode yang digunakan tidak sesuai atau tidak tepat, maka pencapaian tujuan pendidikan yang baik tersebut akan menjumpai atau mengalami beberapa kesulitan. 


\section{b. Kriteria dalam Pemilihan Metode Pembelajaran}

Pemiliham metode pembelajaran yang akan digunakan wajib berorientasi pada tujuan pembelajaran yang ingin dicapai. Sejalan dengan hal tersebut, juga harus disesuaikan dengan jenis materinya, karakter peserta didik, serta pada situasi dan kondisi berlangsungnya proses pembelajaran. Ada beberapa metodemetode yang dapat digunakan oleh pendidik, tetapi tidak semuanya metode sama efektifnya dalam mencapai tujuan yang diinginkan. Untuk itu sangat dibutuhkan kreatifitas atau inovasi guru dalam memilih dan menerapkan metode pembelajaran yang akan digunakan (Nala Rosida 2019:32). Adapun kriteria dalam memilih metode pmebelajaran dengan baik sebagai berikut:

1) Berorientasi pada tujuan pembelajaran. Bagaimana tipe perilaku yang diharapkan untuk dapat dicapai peserta didik

2) Pilih metode pembelajaran yang sesuai dengan keterampilan atau kemempuan yang dimiliki

3) Kembangkan kualitas proses pembelaaran dengan menggunakan media-media pembekajaran yang sesuai. Sehingga peserta didik akan memperoleh rangsangan atau stimulus yang dapat membantu peserta didik dalam memahami dan menguasai materi yang disampaikan (Anisa Muslicha 2015:113).

\section{c. Metode Learning Start with a Question}

\section{1) Pengertian Metode Pembelajaran Learning Start with a Question}

Metode pembelajaran learning start with a question merupakan salah satu metode pembelajaran kooperatif (Agus Suprijono 2016:130). Metode learning start with a question ini secara singkatnya merupakan suatu metode pembelajaran yang dimulai dengan sebuah pertanyaan. Upaya dalam membuat peserta didik aktif dalam bertanya, maka peserta didik diharuskan atau diminta untuk mempelajari materi ajar yang akan dipelajari sebelum ada penjelasan dari pengajar. Metode ini dapat memberikan stimulus peserta didik untuk mencapai kunci belajar, yaitu bertanya. Metode pembelajaran yang dapat menciptakan situasi dan kondisi peserta didik jauh lebih aktif dalam belajar serta dapat mengembangkan kemampuan bertanyanya tentang materi ajar untuk memperoleh hasil dan tujuan yang maksimal. 
Sebelum bertanya, peserta didik dapat dengan membaca terlebih dahulu. Dengan membaca, peserta didik dapat memiliki gambaran tentang materi atau topik yang akan dipelajari. Sehingga apabila dalam membaca menjumpai sebuah kesulitan dan belum bisa dipahami materinya akan terlihat dan dibahas serta diselesaikan dengan bersama-sama. Upaya guru dalam mengatur dan mengontrol peserta didik telah mempelajari materi tersebut, maka guru melakukan pre test. Kemudian misalnya memberikan tugas untuk merangkum dan membuat rangkaian daftar pertanyaan. Sehingga dapat dilihat berapa persen peserta didik yang belajar dan yang tidak belajar (Eka Fitri Puspa 2017:28).

Metode Pembelajaran learning start with a question adalah suatu metode pembelajaran yang dapat memberikat peningkatan pada aktifitas peserta didik dalam belajar. Menurut Silberman, pembelajaran yang dimulai atau diawali dari pertanyaan merupakan proses menggali atau mempelajari hal baru dalam rangka mengefektifkan pembelajaran jika peserta didik dalam kondisi aktif, bukan reseptif. Dengan cara menstimulir peserta didik untuk menyelidiki atau mempelajari sendiri matei ajar, tanpa penjelasan terlebih dahulu dari guru.56 Sedangkan menurut Djamarah, metode learning start with a question merupakan metode yang dapat mengubah pembelajaran menjadi sangat aktif dalam bertanya. Salah satu caranya dengan merangsang peserta didik mengungkapkan sesuatu yang tidak diketahui atau tidak dipahaminya melalui pertanyaan (Saiful Djamarah 2010:399).

Penerapan metode learning start with a question ini diharapkan dapat memberikan konstribusi positif dalam meningkatkan aktivitas belajar peserta didik serta dapat mengatasi masalah, kenyataan, situasi, dan kondisi di kelas yang akan diteliti dan dapat meningkatkan kemampuan bertanya serta meningkatkan hasil belajar peserta didik (Ermidalisma 2016:18).

Jadi metode learning start with a question merupakan metode pembelajaran yang diterapkan untuk meningkatkan keaktifan peserta didik dalam proses pembelajaran di kelas. Partisipasi keaktifan tersebut yang akan 
menciptakan situasi belajar menjadi aktif agar tujuan pembelajaran tercapai dengan tepat dan maksimal.

\section{2) Pelaksanaan Metode Learning Start with a Question}

Cara atau langkah-langkah dari metode pembelajaran learning start with a question dapat dipaparkan sebagai berikut:

a) Pilih satu topik atau bacaan bab tertentu yang akan dipelajari. Dalam hal ini bacaan tidak harus digandakan dengan di fotocopy kemudian dibagikan kepada peserta didik, tetapi dapat dilakukan dengan memilih materi yang sesuaidari buku pelajaran yang digunakan. Usahakan bacaan yang memuatu informasi yang umum atau bacaan yang memberi peluangpeserta didik untuk memberikan tafsiran yang berbeda-beda.

b) Berikan intruksi kepada pesrta didik untuk mempelajari materi yang akan dipelajari sendirian atau bisa dengan temannya.

c) Memberikan intruksi untuk memberikan token atau simbol pada bagian materi yang tidak dipahaminya. Anjurkan untuk memberikan token atau tanda sebanyak-banyaknya. Jika masing memiliki kelonggaran waktu, gabungkan pasangan belajar dengan pasangan lain yang kemudian mintalah mereka untuk mengupas poin-poin yang tidak diketahui yang telah diberi token tadi.

d) Ketika sudah dibentuk kelompok, berikan intruksi untuk menuliskan pertanyaan tentang materi yang telah mereka baca pada masingmasing kelompok.

e) Dari pertanyaan-pertanyaan yang telah dibuat tadi, kumpulkan kepada guru.

f) Sampaikan pelajaran atau materi ajar dengan menjawab pertanyaanpertanyaan tersebut (Agus Suprijono 2016:131).

\section{3) Kelebihan dan Kekurangan Metode Learning Start with a Question}

Shofwatal Qalbiyyah dalam jurnal imliahnya menjelaskan bahwa terdapat kelebihan dan kekurangan dalam metode pembelajaran learning start with a question. Adapun kelebihan dari metode learning start with a question, sebagai berikut: 
a) Siswa lebih siap dalam menghadapi dan memulai pembelajaran, karena telah mempunyai sedikit gambaran mengenai materi yang telah terlebih dahulu dipelajari dan akan lebih paham setelah mendapatkan pemahaman yang sempurna dari guru.

b) Peserta didik sangat aktif dalam berpartisipasi untuk bertanya.

c) Materi atau bacaan dapat lebih diingat oleh siswa.

d) Kecerdasan peserta didik lebih bisa diasah pada saat peserta didik mengajukan pertanyaan pada pembelajaran.

e) Mendorong berkembangnya keberanian peserta didik dalam mengutarakan pendapatnya secara terbuka dan memperluas wawasan yang dimiliki pesrta didik melalui bertukar pikiran.

f) Peserta didik dapat belajar untuk memecahkan masalah sendiri dan bekerjasama dengan teman sebayanya.

g) Dapat mengetahui dengan mudah mana peserta didik yang belajar dan tidak belajar.

Sedangkan kekurangan dari metode learning start wuth a question, sebagai berikut:

a) Jika pertanyaan yang dilontarkan banyak akan memakan waktu yang panjang.

b) Apabila guru memberikan kesempatan untuk peserta didik menjawab bisa melantur jika peserta didik tersebut tidak belajar atau tidak menguasai materi.

c) Apatis bagi peserta didik yang tidak terbiasa berbicara dalam sebuah forum atau peserta didik pasif (Shofwatal Qolbiyyah 2019:154).

\section{Analisis Implementasi Metode Learning Start With a Question di MA Mazro'atul Huda Wonorenggo Karanganyar Demak.}

Metode learning start with a question merupakan salah satu metode yang menggunakan basis dimana anak didiklah yang menjadi pusat pembelajaran. Metode ini bisa dimodifikasi sesuai dengan pelajaran yang akan disampaikan. Pembelajaran akidah akhlak di MA Mazro"eatul Huda Wonorenggo Karanganyar Demak dengan menggunakan metode learning start with a question dapat dikatakan sudah berjalan 


\section{Latifatul Fauziah}

dengan baik dikarenakan adanya interaksi antar guru dan peserta didik yang sesuai. Hal tersebut terlihat peserta didik antusias mengikuti pembelajaran yang bersikap aktif bertanya saat pembelajaran akidah akhlak berlangsung. Peserta didik juga lebih mudah dalam memahami dan peserta didik tidak mudah bosan selama mengikuti pelajaran akidah akhlak. Jadi, ada relevansi antara teori dengan kehidupan nyata bahwa melalui penerapan metode learning start with a question dalam pembelajaran akidah akhlak mampu meningkatkan aktivitas belajar peserta didik serta dapat mengatasi masalah, kenyataan, situasi, dan kondisi di kelas yang akan diteliti dan dapat meningkatkan hasil belajar peserta didik serta kemampuan bertanya

Di dalam pembelajaran akidah akhlak dengan metode learning start with a question yang dilaksanakan di MA Mazro"eatul Huda Wonorenggo Karanganyar Demak juga menggunakan langkah-langkah pembelajaran agar pembelajaran berjalan dengan maksimal sesuai dengan harapan. Langkah-langkah itu meliputi persiapan, pelaksanaan pembelajaran, dan evaluasi:

\section{a. Persiapan}

Persiapan merupakan tahap awal yang harus dilalui setiap kali akan melaksanakan proses pembelajaran. Seorang guru harus mempersiapkan segala sesuatunya agar proses pembelajaran dapat berjalan dengan lancar. Persiapan pribadi yang dilakukan oleh guru mapel akidah akhlak di MA Mazro"atul Huda yaitu persiapan pribadi dan persiapan teknis. Persiapan pribadi dengan mempersiapkan kondisi tubuh yang prima, mulai dari badan secara keseluruhan dan suara. Kondisi tubuh yang prima akan membuat pendidik maksimal dalam melakukan pembelajaran, tidak hanya pendidik tetapi dijelaskan juga bahwa peserta didik juga membutuhkan kondisi yang prima. Kondisi fisik yang kurang mendukung sangat dapat mempengaruhi kualitas belajar anak.

b. Pelaksanaan

Tahapan inti dari langkah-langkah pembelajaran akidah akhlak selanjutnya adalah tahap pelaksanaan tindakan berupa pembelajaran akidah akhlak. Sebagai suatu seni, metode belajar harus dapat menimbulkan kesenangan dan kepuasan bagi peserta didik. Adapun langkah-langkah tersebut diantaranya:

1) Kegiatan Pedahuluan 
Pendahuluan yang ditempuh oleh guru akidah akhlak di MA Mazro"eatul Wonorenggo Karanganyar Demak selama 10 menit sebelum kegiatan belajar mengajar dimulai, guru membuka kegiatan pembelajaran dengan mengucapkan salam dan menanyakan bagaimana kabar peserta didik Tetapi guru tidak melakukan absensi peserta didik karena pelajaran di kelas $\mathrm{X}$ IPA 1 pada jam akhir. Selanjutnya pendidik melakukan review secara singkat terkait materi pelajaran yang telah lampau dengan bertanya kepada peserta didik. Kegiatan tersebut dilakukan untuk mengetahui sejauh mana ingatan peserta didik terhadap materi pelajaran sebelumnya. Kemudian guru memberikan motivasi untuk menambah stimulus peserta didik dalam menerima materi pembelajaran yang baru.

2) Kegiatan Inti

Penerapan metode learning start with a question dalam kegiatan pembelajaran yang dilakukan oleh guru mata pelajaran akidah akhlak di MA Mazro"atul Huda Wonorenggo Karanganyar Demak yaitu kegiatan ini dimulai dengan guru mapel akidah akhlak membentuk beberapa kelompok-kelompok kecil terdiri dari satu kelompok 5 peserta didik. Sedangkan peserta didik menerima intruksi dan segera merapat dengan kelompok masing-masing yang telah di tentukan oleh guru. Sebelum pembagian kelompok, pada pertemuan sebelumnya guru sudah memberikan materi atau topik yaitu materi "Menghindari Akhlak Tercela (Tercela, licik, tamak, zalim, dan diskriminasi)" untuk dipelajari peserta didik dan diberi intruksi untuk memberikan token atau simbol pada materi yang belum atau tidak dipahami. Kelompok tersebut yang nantinya berdiskusi membuat pertanyaan maupun menjawabnya sekaligus guru menyampaikan aturan main metode learning start with a question di kelas $\mathrm{X}$ IPA 1. Kemudian di dalam kelompok kecil, guru memberikan satu kertas pada masing-masing kelompok untuk menuliskan pertanyaan yang nantinya dikumpulkan setelah menerima aba-aba dari guru mapel. Ketika guru memberikan intruksi "Silahkan kumpulan semua pertanyaan dari masingmasing kelompom ke depan!" maka langkah selanjutnya yaitu semua pertanyaan dikumpulkan. 
Sebelum guru menjawab pertanyaan yang didiskusikan, guru menawarkan kepada kelompok lain untuk menjawab pertanyaan kelompok temannya. "Sebelum saya jelasakan, dari kelompok lain ada yang ingin memberikan jawaban, silahkan!"

Kelompok yang lain langsung merespon untuk mencoba menjawab pertanyaan meskipun tidak semua benar. Kemudian guru akidah akhlak menjawab pertanyaan dengan penjelasan yang sesuai dengan pemikiran peserta didik disertai dalilnya sekaligus menjelaskan sebagian materi mengenai menghindari akhlak tercela (Licik, tamak, zalim dan diskriminasi) sebagai penguatan atas pemahaman peserta didik dengan dibantu media pendukung berupa LCD dan proyektor. Dengan menggunakan dan memanfa ${ }^{e e}$ atkan media pembelajaran yang disediakan madrasah dengan baik diharapkan mampu meningkatkan pemahaman bagi peserta didik dimana media pembelajaran juga termasuk faktor pendukung dari pembelajaran.

3) Penutup

Tahap ini adalah kegiatan penutup berlangsung selama 10 menit. Kegiatan ini diisi dengan guru akidah akhlak memberikan penguatan dan bersama peserta didik menyimpulkan sebagian materi menghindari akhlak tercela yang telah diajarkan. Selanjutnya, guru akidah akhlak menjelaskan materi secara singkat terkait materi yang akan dipelajari pada pertemuan berikutnya dan meminta peserta didik untuk mempelajari di rumah. Pada akhir pembelajaran, guru menutup dengan bacaan hamdalah, berdo ${ }^{\text {ee } a}$ bersama menutup akhir pelajaran serta mengucapkan salam.

c. Evaluasi

Evaluasi merupakan langkah pembelajaran terakhir yang harus dilakukan oleh seorang pendidik. Evaluasi dilakukan untuk mengetahui serta mengumpulkan, pemahaman, pengetahuan dan keberhasilan peserta didik dalam menyerap materi yang telah diajarkan oleh pendidik. Evaluasi juga dilakukan oleh pendidik mata pelajaran akidah akhlak melalui banyak cara. Berdasarkan hasil observasi yang peneliti lakukan, proses atau tahap evaluasi yang diberikan guru mapel akidah akhlak di kelas X IPA 1 MA mazro ${ }^{e c}$ atul Huda mengenai gambaran kemajuan pemahaman peserta didik dengan memberikan tugas mengerjakan sebagian soal 
yang ada di LKS masing-masing, memperhatikan sikap bertanggung jawab dengan kelompok masing-masing seperti contoh menyusun hasil diskusi kelompok dan lain-lain serta sikap peserta didik dalam menjalin komunikasi baik dengan kelompoknya dan bagaimana keaktifan atau partisipasi peserta didik dalam berdiskusi. Kemudian peserta didik juga mengemban tugas dalam menjawab, menjelaskan atau mempresentasikan hasil diskusi kelompok dengan baik serta kekompakan tim atau kelompok dalam mempresentasikan hasil tersebut.

\section{SIMPULAN}

Berdasarkan pembahasan dan analisis data yang telah dipaparkan di bab sebelumnya tentang implementasi metode learning start with a question pada pembelajaran akidah akhlak di MA Mazro'atul Huda Wonorenggo Karanganyar Demak dapat disimpulkan sebagai berikut:

MA Mazro'atul Huda Wonorenggo Karanganyar Demak memiliki langkahlangkah pembelajaran akidah akhlak dengan metode learning start with a question ini sangat menyeluruh artinya langkah-langkah pembelajaranya sudah terencana dan terstruktur dengan rapi. Metode ini dimulai dengan guru mapel akidah akhlak memberikan satu topik atau materi yang akan dipelajari, kemudian memberikan intruksi untuk mempelajari dan memberikan token pada bagian yang belum atau tidak dipahami, guru membentuk beberapa kelompok-kelompok kecil untuk nantinya berdiskusi membuat pertanyaan maupun menjawabnya. Selanjutnya pada masingmasing kelompok untuk menuliskan pertanyaan yang nantinya dikumpulkan setelah menerima aba-aba dari guru mapel. Setelah semua pertanyaan dikumpulkan, guru mapel akidah akhlak akan menjawab pertanyaan-pertanyaan tersebut dengan mengkaitkan materi menghindari akhlak tercela. Sebelum guru menjawab pertanyaan yang didiskusikan, guru menawarkan kepada kelompok lain untuk menjawab pertanyaan kelompok temannya. Kemudian guru akidah akhlak menjawab pertanyaan dengan penjelasan yang sesuai dengan pemikiran peserta didik disertai dalilnya sekaligus menjelaskan dengan dibantu media pendukung berupa LCD dan proyektor serta diberikan evaluasi pada akhir pembelajaran. 
Faktor pendukung implementasi metode learning start with a question pada pembelajaran akidah akhlak di MA Mazro'atul Huda Wonorenggo Karanganyar Demak diantaranya: sarana prasarana misalnya media pembelajaran yang digunakan, dari mediator atau pendidik, peserta didik dan kelebihan dari metode learning start with a question itu sendiri.

Disamping faktor pendukung seperti yang telah diuraikan, dalam penerapan metode ini juga terdapat beberapa faktor penghambat diantaranya yaitu waktu yang sangat terbatas dan faktor dari peserta didik dalam pembelajaran akidah akhlak.

\section{DAFTAR PUSTAKA}

Alwi, Said."Problematika Guru dalam Pengembangan Media Pembelajaran," Jurnal Itqan $\quad 8, \quad$ no. 2019 (2017)https://ejurnal.iainlhokseumawe.ac.id/index.php/itqan/article/download/107/65.

Amri, Reisa Farida dan Triani Ratnawuri, "Pengaruh Penggunaan Strategi Pembelajaran Peningkatan Kemampuan Berpikir (SPPKB) terhadap Hasil Belajar Kewirausahaansiswa Kelas XI Semester Genap SMK Muhammadiyah 2 Metro T.P 2015/2016," Promosi Jurnal Pendidikan Ekonomi 4, no. 1 (2016)- 15 Oktober, 2019- http://ojs.fkip.ummetro.ac.id/index.php/ekonomi/article/viewFile/475/42.

Anggresta, Vella, Busthari Mucthar, dan Marwan. "Analisis Faktor-faktor yang mempengaruhi Prestasi Belajar Mahasiswa Fakultas Ekonomi Universitas Negeri Padang," Jurnal Pakar Pendidikan 14, no. 1 (2016)- 17 November, 2019 http://ejournal.stkippgrisumbar.ac.id/index.php/economica/article/download/325/1.

Ardy Novan dan Barnawi. Ilmu Pendidikan Islam. Jogjakarta: Ar-Ruzz Media, 2016, 185.

Arifin. Upaya Menjadi Guru Profesional. Bandung: ALFABETA, 2017.

Arikunto Suharsimi. Prosedur Penelitian Suatu Pendekatan Praktek. Jakarta: Rineka Cipta, 120-123.

Aristin, Nevy Farista. "Faktor-faktor yang Berpengaruh terhadap Anak Putus Sekolah Tingkat Sekolah Menengah Pertama (SMP) di Kecaatan Bondowoso," Jurnal 
Pendidikan Geografi 20, no. 1 (2015)- 17 November, 2019http://journal.um.ac.id/index.php/pendidikangeografi/article/viewFile/5009/1763.

Baharuddin. Pendidikan dan Psikologi Perkembangan. Yogyakarta: Ar-Ruzz Media, 2006.

Daradjat, Dzakiyah. Metodik khusus Pengajaran Agama Islam. Jakarta: Bumi Aksara, 2001.

Djamarah, Saiful. Guru dan Anak didik dalam Interaksi Edukatif. Jakarta: Rineka Cipta, 2010.

Ernidalisma. "Penerapan Metode Pembelajaran Learning Start with a Question untuk Meningkatkan Hasil Blajar Matematika pada Siswa Kelas VIII-6 SMP Negeri 30 Pekanbaru Tahun Pelajaran 2015/2016," Jurnal Ilmu Pendidikan Sosial, sains, dan Humaniora 1, no. 1 (2015)- 18 November, 2019http://ejournal.uinsuska.ac.id/index.php/suaraguru/article/download/2027/1381.

Gunawan, Heri. Pendidikan Islam Kajian Teoretis dan Pemikiran Tokoh. Bandung: PT. Remaja Rosdakarya, 2014.

Hamdani. Strategi Belajar Mengajar. Bandung: Pustaka Setia: 2011.

Hamruni. Strategi dan Model-Model Pembelajaran Aktif- Menyenangkan. Yogyakarta: Fakultas Tarbiyah UIN Sunan Kalijaga, 2009). Hardivizon. "Metode Pembelajaran Rasulullah Saw (Telaah Kualitas dan Makna Hadis)," Jurnal Pendidikan Islam 2, no. 2 (2017)- $12 \quad$ Desember, http://journal.iaincurup.ac.id/index.php/belajea/article/download/287/198.

Kadir, Abdul. Dasar-dasar Pendidikan . Jakarta: Kencana Prenadamedia Group: 2014.

Kurniawan, Indra, Agus Wahyuddin, dan Yati Nurhayati. "Implementasi Customer Relationship Management Pada Penjualan di Koperasi Mawar Garawangi,” Jurnal Teknologi Informasi 10, no. 2 (2016)- 03 Desember, 2019 https://www.journal.uniku.ac.id/index.php/ilkom/article/download/996/700.

Muammar, dan Suhartina. "Media Pembelajaran Berbasis Teknologi Informasi dalam Meningkatkan Minat Belajar Akidah Akhlak," Kuriositas: Jurnal Media 
Komunikasi Sosial dan Keagamaan 11, no. 2 (2018)- 20 November, 2019https://ejurnal.iainpare.ac.id/index.php/kuriositas/article/download/728/491

Muchit, Saekhan. Pembelajaran Kontekstual. Semarang: RaSAIL Media Group, 2008.

Muslicha, Anisa. "Metode Pengajaran dalam Pendidikan Lingkungan Hidup Pada Siswa Sekolah Dasar (Studi Pada Sekolah Adiwiyata DKI Jakarta)," JurnalPendidikan 16, no. 2 (2015)- $25 \quad$ November, http://www.jurnal.ut.ac.id/index.php/jp/article/download/342/318.

Nopi dan Iin Nurbudiyani, "Upaya Meningkatkan Hasil Belajar Ekonomi dengan Menggunakan Metode Pembelajaran Learning Start with a Question pada Perserta Didik," Neraca: Jurnal Pendidikan Ekonomi 3, no. 1 (2017) - 12 Oktober2019http://journal.umpalangkaraya.ac.id/index.php/neraca/article/downloa d/932/849.

Pradana, Lingga Nico. "Keefektivan Metode Learning Starts with a Question pada Pembelajaran Geometri', Jurnal Profesi Pendidikan Dasar 3, no. 1 (2016)- 15 Oktober 2019http://journals.ums.ac.id/index.php/ppd/article/download/2715/1763.

Purwanto, Ngalim. Psikologi Pendidikan. Bandung: Remaja Rosdakarya, 2004.

Qolbiyyah, Shofwatal. "Penerapan Metode LSQ (Learning Start with a Question) dalam Upaya Meningkatkan Hasil Belajar Siswa," Jurnal Sumbula 4, no. 1 (2019)- 12 Oktober

http://ejournal.kopertais4.or.id/mataraman/index.php/sumbula/article/view/3656.

Rahmat, Didin. "Implementasi Kebijakan Program Bantuan Hukum bagi Masyarakat Tidak Mampu di Kabupaten Kuningan," Jurnal Unifikasi 04, no. 1 (2017) - 28 November, https://www.journal.uniku.ac.id/index.php/unifikasi/article/download/478/396.

Riyani, Yani. "Faktor-faktor yang Mempengaruhi Prestasi Belajar Mahasiswa (Studi pada mahasiswa Jurusan Akuntansi Politeknik Negeri Pontianak),” Jurnal Eksos 8, no. 123 (2015)- 2020 http://repository.polnep.ac.id/xmlui/handle/123456789/354. 
Rosida, Nala, dan Moh. Turmudi. "Metode Collaborative untuk Meningkatkan Pemahaman Siswa Pada Materi al-Qur'an Hadist Kelas X IPS 2 MA Al Mahrusiyah," el-Bidayah: Jurnal of Islamic Elementary Education 1, no. 1 (2019)05

Desember, 2019-

https://ejournal.iaitribakti.ac.id/index.php/pgmi/article/download/675/471.

Sarani, Dimas Ahmad. "Metode Pengajaran dalam Pendidikan Agama Islam," Jurnal AlFatih 4, no. 1 (2015)- $05 \quad$ Desember, 2019http://ejournal.kopertais4.or.id/mataraman/index.php/alfatih/article/view/1266/897.

Sari, Eka Fitri Puspa. "Pengaruh Kemempuan Pemahaman Konsep Matematika Mahasiswa melalui Metode Pembelajaran Learning Starts with a Question," Jurnal Mosharafa 6, no. 1 (2017)- $07 \quad$ November, 2019https://journal.institutpendidikan.ac.id/index.php/mosharafa/article/viewFile/mv6n 1 3/296.

Silberman. Active Learning: 101 Cara Belajar Siswa Aktif. Bandung: Penerbit Nusamedia, 2006.

Sudarman, Satrio Wicaksono dan Ira Vahlia, "Efektifitas Penggunaan Metode Pembelajaran Quantum Learning terhadap Kemampuan Pemahaman Konsep Matematis Mahasiswa," Al-Jabar: Jurnal Pendidikan Matematika 7, no. 2 (2016) 12 Oktober 2019

http://ejournal.radenintan.ac.id/index.php/aljabar/article/viewFile/42/36.

Suprijono, Agus. Cooperative Learning: Teori \& Aplikasi PAIKEM. Yogyakarta: Pustaka Pelajar, 2016.

Suprihatiningrum, Jamil. Strategi Pembelajaran Teori dan Aplikasi. Jogjakarta: Ar-Ruzz Media, 2017.

Suryadarma, Yoke dan Ahmad Hifdzil Haq, "Pendidikan Akhlak Menurut Imam AlGhazali," Jurnal At-Ta'dib 10, no. 2 (2015)- 17 November, 2019http://ejournal.unida.gontor.ac.id/index.php/tadib/article/viewFile/460/417.

Suryawati, Dewi Prasari. "Implementasi Pembelajaran Akidah Akhlak terhadap Pembentukan Karakter Siswa di MTs Negeri Semanu Gunungkidul," Jurnal 
Latifatul Fauziah

Pendidikan Madrasah 1, no. 2 (2016) - 15 oktober, 2019http://ejournal.uinsuka.ac.id/tarbiyah/index.php/JPM/article/download/1218/1106.

Usman, Uzer. Menjadi Guru Profesional. Bandung: Remaja Rosdakarya, 2006.

Widyanto, Putri. "Implementasi Manajemen Pembelajaran Saintifik di Institut Agama Hindu Negeri Tampung Penyang Palangka Raya," Jurnal Studi Agama 2, no. 1 (201925

November

2019 ,

https://download.atlantispress.com/article/55910636.pdf. 